Journal of Educational Method and Technology Vol. 2 No. 3, Desember 2019

P-ISSN 2622-8459 E-ISSN 2622-8467

http://ejournal.unima.ac.id/index.php/jemtec

\title{
The Use Of Teaching Media In Expression Orale (Speaking) Class At French Education Study Program
}

\author{
W E Sekeh ${ }^{1}$ \\ ${ }^{1}$ Universitas Negeri Manado, Indonesia \\ corresponding author: ${ }^{1}$ wiesjesekeh@unima.ac.id
}

\begin{abstract}
The purpose of this study is to find and describe the use of teaching media and find out its role in improving students' learning outcomes at French Language Education Study Program of Manado State University. This research uses classroom action research methods. The results show that the use of teaching media effectively improved student learning outcomes by increasing stundents' mastery of learning subject by $20 \%$ and increasing student learning outcomes by $11.34 \%$. The use of teaching media makes the teaching and learning process more interesting and arouses student interest and motivation.
\end{abstract}

Keywords: teaching media, CAR, learning outcomes, interests, motivation.

\section{Introduction}

In order to master a foreign language, students have to develop knowledge of the language they are learning. Besides, they ought to have interest in that particular language and motivation to develop language skill or communication skill of the language they are learning. It is so because the learning of a different new language is a difficult and demanding task. At least it is true for Indonesian students learning French, especially at French Language Education Study Program of Manado State University.

One of the subjects in French education curriculum is Expression Orale. The objective of this subject is to develop students' speaking skill in French language. In Expression Orale class students learn and practice to communicate in French. In the teaching process of Expression Orale or speaking skill, the use of instructional media is very important. One of the real practical benefits of learning with instructional media is the increase of students' interest, motivation and learning outcomes.

One of the determining factors for success or failure of the teaching and learning process lies in whether or not a teacher chooses media that is suitable with the subject matter. Through the use of appropriate instructional media students will be more passionate and therefore can improve their learning outcomes. For example, in teaching time / hour the right media is not audio or video media but image media. On the other hand, if the subject matter is the correct pronunciation of words, the right media to use is audio media. Likewise, in teaching about culture, the life of French people, or a general introduction to the country of France the appropriate teaching media is video media. 
Journal of Educational Method and Technology Vol. 2 No. 3, Desember 2019

P-ISSN 2622-8459 E-ISSN 2622-8467

http://ejournal.unima.ac.id/index.php/jemtec

\section{Literature Review}

The word "media" comes from Latin and is a plural form of the word "medium" which literally means an intermediary. Gagne states that the media are various types of components in the student environment that can stimulate them to learn. Briggs believes that the media are all physical tools that can present messages and stimulate students to learn. Books, films, tapes, videos are examples.

On the other hand the experts define that the media when understood in broad outline is human, material or event that builds conditions that make students able to obtain knowledge, skills or attitudes. In this sense, teachers, textbooks, and the school environment are media. And other restrictions put forward by media experts as all forms and channels used to convey messages or information. Aside from being a delivery or delivery system, media are often replaced by the word mediator. Thus it can be understood that the media are intermediaries that deliver information from sources to recipients of information. According to Arsyad (2013), television, films, photos, radio, audio recordings, video projected images, printed materials and the like are communication media, and if the media carries instructional messages or contains teaching purposes then the media are called learning or teaching media.

It means that all tools used in instructional communication can be called instructional media which implicitly includes tools that are physically used to deliver learning material such as books, tape recorders, tapes, videos, cameras, video recorders, films, slides, photos, pictures, graphics, television and computers. In other words instructional media is a component of learning resources or a physical vehicle that contains instructional material and is able to stimulate learners to learn.

\section{Graphic Media}

The most commonly used graphic media is image or photo media. Graphic media is a common language, which can be understood and enjoyed everywhere. Using pictures, learners can practice to tell a short story or describe a situation of event, to provide oral information, to interpret everything in the picture.

The advantages of graphic media are as follows:

1) Concrete nature; pictures / photos are more realistic addressing the subject matter compared to verbal media;

2) Images can overcome space and time limiations. Not all objects and events can be brought in class, and not always children can be brought to those objects / events.

3) Image / photo media can overcome the limitations of our observations.

4) Photos can clarify a problem, in any field and at any age level, so as to prevent and correct errors.

5) Photos are cheap and easy to get and use, without the need for special tools. (safei, 2007)

\section{Audio Media}

Audio media is closely related to hearing because the message conveyed through auditive symbols, both verbal and non verbal. There are several types of media that can be classified in audio media, i.e. radios, sound recording devices, vinyl records and language laboratories. 
Journal of Educational Method and Technology Vol. 2 No. 3, Desember 2019

P-ISSN 2622-8459 E-ISSN 2622-8467

http://ejournal.unima.ac.id/index.php/jemtec

The function of the audio media are:

1) Provide opportunities for learners to practice inside and outside the classroom.

2) Facilitate, complement and help the teacher in his teaching.

3) Give a fixed (unchanging) model to learners, especially records that contain a certain repetition and intonation

4) By listening to the voice of native speaker, learners can distinguish the voices of women, men, children and all its variations

5) Teachers can use the recording of students' speeches to evaluate foreign language mastery and similarly learners can evaluate themselves their utterances or speeches (Fitria, A. (2014).

\section{Radio}

As a media, radio has several advantages compared to other media, including (a) the price is cheap and the program varies; (b) easy to move; (c) can overcome schedule problems because the program can be recorded and played back; (d) can develop imagination; (e) can stimulate the active participation of listeners; (f) can focus attention; (g) broadcasts by voice prove to be very appropriate / suitable for teaching music and language; (h) can do certain things better than the teacher; (i) can do things that the teacher cannot do; can overcome space and time limitations because of its wide reach.

As with other learning media, radio media also has weaknesses including; (a) the nature of communication is unidirectional; (b) broadcasts are centralized so that the teacher cannot control them; (c) scheduling lessons and broadcasts often creates problems and the integration of radio broadcasts in class is often difficult (Sadiman, 2007).

\section{Language laboratory}

The language laboratory is a tool to drill students in listening and speaking a foreign language. The media used are recording devices. In language laboratory students sit individually in booths. Students hear teacher's voice from control room through headphones. When a students imitate the teacher's words, they hear their voice through their headphones as well. Therefore, he can compare his utterances with the teacher's and thus he can immediately correct his mistakes (Ofemile, 2018).

\section{Video}

As an audio-visual media the use of video in teaching and learning is increasingly became popular. It is because the message delivered can be facts (important events / events, news) and fictions, can be normative, educative or instructional. In most cases, videos can replace films as teaching media.

The advantages of video as a medium of learning are:

1) Can attract attention for a short period;

2) Video recording can be used to obtain information from experts / specialists;

3) Difficult demonstrations can be recorded and prepared in advance;

4) Saves time and can be played back;

5) Easy to adjust the volume;

6) The teacher can arrange the part to be watched with pause button; 
Journal of Educational Method and Technology Vol. 2 No. 3, Desember 2019

P-ISSN 2622-8459 E-ISSN 2622-8467

http://ejournal.unima.ac.id/index.php/jemtec

7) No. need to darken the classroom.

The weaknesses of video as teaching media are,

a. Difficult to control audience's attention;

b. The communication is unidirectional;

c. Less able to display details of the object presented;

d. Need complex equipment. (fadhl, 2015)

\section{Game and Simulation}

Game is a contest between players who interact with each other by following certain rules to achieve goals. Game has 4 main components such as: 1) Players; 2) Environment where the players interact; 3 ) The rules of the game; 4) Objectives to be achieved.

Simulation simplify reality to reflects the actual situation. It is operational, meaning that it must describe the process. Role play is somewhat different because it must contain 3 components; 1)The scenario or environment in which the action took place; 2) There are a number of roles with various characters that must be performed; 3) There are problems that must be solved by the players/students. (Prihadi,2010)

\section{The Function of Teaching Media}

Teaching media are effective and efficient when used in learning process in accordance with the function i.e:

1) Clarify the presentation of the message so as not to be too verbalistic (in the form of written words);

2) Overcome the limitations of space, time and senses;

3) Appropriate usage of various teaching media can address passive students because media can arouse excitement of learning, allow more direct interaction between students with the environment and reality, and allow students to learn independently according to their abilities and interests;

4) The fact that each student is unique in his/her environment and life experience, while the curriculum and educational materials are designed the same for each student, make many instructors have difficulties in doing everything alone. (sadiman 2007: 17, 18)

Based on the function and benefits of teaching media it is strongly recommended to use it in the learning process by taking into account the teaching objectives. Its use must indicate the function of instruction where information through the media engages students in the mind or mental as well as tangible forms of activity where learning takes place. Arsyad (2013) states the function of the media, especially visual media, are (a) attentive function; (b) affective function; (c) cognitive function; (d) compensatory function.

The attentive function of visual media works to attract and direct students' attention and to concentration. The affective function of visual media can be seen from the level of learner enjoyment when studying or reading. The cognitive function of visual media is apparent from the research findings which reveal that the visual or image symbol facilitates understanding and memorization of information or messages. The compensatory function of instructional media can be seen from the results of research that visual media by providing context for understanding texts help learners in organizing information and recalling it. 
Journal of Educational Method and Technology Vol. 2 No. 3, Desember 2019

P-ISSN 2622-8459 E-ISSN 2622-8467

http://ejournal.unima.ac.id/index.php/jemtec

\section{Benefits of Media}

Arsyad (2013) stated the results of research showing the positive impact of using media as an integral part of learning: 1) Standardization of lessons; 2) Learning becomes more interesting; 3) Learning becomes more interactive; 4) The shortening of learning duration; 5) The improvement of quality of learning outcomes; 6) Learning can be done anywhere and anywhere; 7) The increases of students' positive attitude; 8) The teacher's role changes in a positive direction, repeated explanations can be avoided.

\section{Learning, Learning Outcomes and Evaluation}

Learning and teaching are interactions or reciprocal relationships between instructors and students that are always marked by the objectives to be achieved, learning material, the existence of methods, media and evaluation.

Dimyati and Mudjiono (2013) state that students obtain learning outcomes through the act of learning. From the teacher's point of view the teaching action ends with the process of evaluating learning outcomes and from students' point of view learning outcomes are the end and the peak of the learning process. Hamalik (2009) stated that student learning outcomes are a pattern of behavior which is the final peak of the teaching and learning process. Mulyasa (2008) said the learning outcomes are learning achievements which overall became indicators of students' competence and the degree of change in their behavior.

Learning evaluation is the act of determining the degree of mastery of certain subjects by individuals or groupsof students. The process is generally studentcentered, aim to observe student learning outcomes, and assess the extent to which instructional media succeed in conveying instructional messages to students. Ibrahim and Syaodih (2003) suggest that there are two evaluation functions, namely: (a) knowing the effectiveness of the program and achieving its objectives; (b) identifying the parts of the learning program that need to be improved. According to Mulyasa (2008) the evaluation of learning outcomes is essentially an activity to measure the change in behavior that has occurred and will have an influence in two forms: (a) participants will have a perspective on their strengths and weaknesses over desirable behavior, (b) they find that the desired behavior has increased in stages or two stages.

\section{Research Objectives}

This study aims to provide a description of 1) The use of teaching media in the process of learning French in the French Language Education Study Program of Manado State University and 2) The use of teaching media in the process of learning French in the French Language Education Study Program of Manado State University in order to improve student learning outcomes.

The research provide the following benefits as well; 1) Creating a more interesting learning atmosphere; 2) Creating a learning atmosphere that is practical and able to increase student motivation in learning French; 3) Giving students insight into France with authentic images about the country of France for the purpose of fostering students' interest in learning French; 4)Drill students to say French phrases or sentences with the right intonation; 5) Evoke students' curiosity about French language and country and 6) Motivate students to learn French 
Journal of Educational Method and Technology Vol. 2 No. 3, Desember 2019

P-ISSN 2622-8459 E-ISSN 2622-8467

http://ejournal.unima.ac.id/index.php/jemtec

\section{Research Methods and Techniques}

The research method used is the classroom action research (CAR) method.

The steps for implementing class actions are as follows.

1) Read the dialog 3 times without interruption

2) Ask students to repeat every word and sentence in the material

3) Give a brief explanation of the subject

4) Ask questions about the material being taught

5) Ask students to do exercises about the material being taught. (Nizar, 2008).

The next stage of repetition includes:

1) Listen to recordings while showing material via the lcd

2) Ask students to repeat words and sentences

3) Improve students' pronunciation and intonation

4) Playing more sound recordings to students adjusting and correcting mistakes

5) Question and answer (post-test) about the material being taught

Data analysis uses calculation the percentage and average learning outcomes

of each stage of the CAR. Improving the ability and skills to carry out learning and student learning outcomes is done by comparing the results of learning achievement in the research cycles. Students are declared successful if they reach the 75\%

Minimum Mastery Criteria with learning outcomes obtained by students in each cycle.

\section{Results And Discussion}

From the observations made before the research, it is clear that the use of teaching media can improve learning outcomes in expression orale class. The teaching process of expression orale using instructional media has two cycles. Each cycle follows this steps; 1) Plan; 2) Action and Observation; 3) Evaluation; 4) Reflection.

In the first cycle the teaching process did not use instructional media. Observation indicate that there were students who seemed uninterested and did not show positive responses. There are a number of students who don't pay attention and don't even hear instructions. After implementing the action in the first cycle, the constraints found are:

a. Students' interest in expression orale subject cannot be seen. The learning method makes them indifferent in the learning process.

b. Students' motivation to find out things they did not understand is almost nonexistent. It seemed that students did not care about words or expressions they did not understand.

In the second cycle the teaching process used instructional media.

a. The learning process design is different from cycle I

b. The subject is nationality

c. The language element is the verb être (to be).

The implementation of the second cycle of action is an effort to improve the teaching and learning process of cycle I which did not use instructional media. The implementation is as follows: 
Journal of Educational Method and Technology Vol. 2 No. 3, Desember 2019

P-ISSN 2622-8459 E-ISSN 2622-8467

http://ejournal.unima.ac.id/index.php/jemtec

a. Design of teaching process and preparation of learning material about nationality. The basic competence is correct pronunciation of one's nationality or the nationality of others.

b. Students learned the conjugation of the verb être for the first and second and third subjects, namely je, $t u$ and $i l$.

Observation of cycle II shows that students' attention and interest are increased, that it facilitates classroom management and the teaching and learning process becomes conducive. Evaluation shows the following results:

There are 15 students participating in the study. The result is as follows:

$\square 1$ student gained score 95

$\square 1$ student gained score 90

$\square 3$ students gained score 85

$\square 4$ students gained score 80

$\square 3$ students gained score 75

$\square 3$ students gained score 60

From the range of scores it can be concluded that the use of instructional media is very effective and able to motivate learners to improve their learning outcomes.

\section{Results of Cycle I}

Based on the evaluation of student learning outcomes in the first cycle of action the following data are obtained:

\begin{tabular}{ccc}
\hline \multirow{2}{*}{ Learning outcomes } & \multicolumn{2}{c}{ Mastery } \\
\cline { 2 - 3 } & Yes & No \\
\hline $66.33 \%$ & $56 \%$ & $44 \%$ \\
\hline
\end{tabular}

The table shows students' mastery of subject when they are taught without the usage of instructional media are 56\%. Observations of teaching process in classroom shows that there are students who were less serious and did not show positive responses to the lesson. There are a number of students who don't pay attention and don't even hear instructions.

\section{Results of Cycle II}

Learning outcomes and mastery of the subject in cycle II are as follows:

\begin{tabular}{ccc}
\hline \multirow{2}{*}{ Learning outcomes } & \multicolumn{2}{c}{ Mastery } \\
\cline { 2 - 3 } & Yes & No \\
\hline $77.67 \%$ & $80 \%$ & $20 \%$ \\
\hline
\end{tabular}

The table shows students' mastery of subject and their mastery increased. Observations of teaching process in classroom shows that students were interested and show positive responses to the lesson.

\section{Reflection}

Evaluation shows big difference in students learning outcomes. There is an increase in the quality of learning. This can be seen in the attitude of students participating in learning activities. It shows that the use of proper instructional media makes the teaching and learning become more interesting, and process more effective and efficient. The results of this study confirmed the study about the power 
Journal of Educational Method and Technology Vol. 2 No. 3, Desember 2019

P-ISSN 2622-8459 E-ISSN 2622-8467

http://ejournal.unima.ac.id/index.php/jemtec

human senses on learning, especially sight and hearing. Such study concluded that sight plays biggest role in human learning namely $85 \%$, followed by hearing $11 \%$. The other three senses fill the rest: smell $3.5 \%$, touch $1.5 \%$ and taste $1 \%$ (Rosenblum, 2010; Stolovitch \& Keeps, 2011; Medina, 2008). Students learn in learning enveironment that used visual media very likely will get good results.

\section{Conclusion}

Based on the results of this study it can be concluded that the use of instructional media really helps the learning and teaching process and effectively improves learning outcomes and it is certain that learning and teaching expression orale by using media can foster greater motivation and interest in expression orale.

As for the results obtained from 15 students who attended French language lectures, there were only 3 students who could not reach the mastery stage, because they only got a score of 60 , while those who reached the level of mastery were 12 students. Mastery level increased to $80 \%$ from $64 \%$ after the students learned using instructional media. It indicates that learning outcomes really improved and the process of learning with the media gave expected results.

\section{References}

Arsyad, A. (2013). Media Pembelajaran. Jakarta: Rajawali Pers.

Dimyati \& Mudjiono. (2013). Belajar dan Pembelajaran. Jakarta: Rineka Cipta

Fadhl, M. (2015). Pengembangan Media Pembelajaran Berbasis Video Kelas IV Sekolah Dasar. Jurnal Dimensi Pendidikan dan Pembelajaran, 3(1), pp. 24-29.

Fitria, A. (2014). Penggunaan Media Audio Visual dalam Pembelajaran. Cakrawala Dini, 5 (2). pp. 57-62.

Hamalik, O. (2009). Proses Belajar Mengajar. Jakarta: Bumi Aksara.

Ibrahim, R. \& Syaodih, N. (2003). Perencanaan Pengajaran. Jakarta: Rineka Cipta

Medina, J. (2008). Brain Rules: 12 principles for surviving and thriving at work, home, and school. Seattle: Pear Press

Mulyasa, E. (2008). Menjadi Guru Profesional Menciptakan Pembelajaran Kreatif dan Menyenangkan. Bandung: Remaja Rosdakarya.

Nizar, A. (2008). Classroom Action Research. Bandung: Rahayasa.

Ofemile, A. Y. (2018). Multimedia Language Laboratory and Language Teaching and Learning in Open and Distance Education in Nigeria. British Journal of Education, Learning and Development Psychology, 1(1), pp.74-84

Prihadi. (2010). Media Pembelajaran. Jakarta: Direktorat Jendral Pendidikan Lanjutan Pertama, Kemendiknas

Rosenblum, L.D. (2010). See what I'm saying: The extraordinary Powers of our five senses. New Yord: W.W.Norton \& Company

Sadiman, A. S., et al. (2007). Media Pendidikan. Jakarta: Raja Grafindo Persada.

Safei. (2007). Penggunaan Media Grafis dalam Pembelajaran. Lentera Pendidikan 10(1) pp. 116-123.

Stolovitch, H. D. \& Keeps, E. J. (2011). Telling Ain't Training: Updated, expanded, enhanced. Alexandria: Association for Talent Development. 